\title{
Reduced insulin-like growth factor-I mRNA content in liver, adrenal glands and spinal cord of diabetic rats
}

\author{
D.N. Ishii ${ }^{1}$, D. M. Guertin ${ }^{1}$, L. R. Whalen ${ }^{2}$ \\ ${ }^{1}$ Department of Physiology, Colorado State University, Fort Collins, Colorado, USA \\ ${ }^{2}$ Department of Anatomy and Neurobiology, Colorado State University, Fort Collins, Colorado, USA
}

Summary Circulating insulin-like growth factor I (IGF-I) concentrations are known to be reduced in experimental and clinical diabetes mellitus. The IGF-I mRNA content was measured in several tissues of rats treated with streptozotocin to determine whether a correlation with neuropathy could be found. IGF-I mRNA content was sharply reduced relative to total and poly $(\mathrm{A})^{+}$RNA in diabetic liver and adrenal glands. In contrast, histone $3.3 \mathrm{mRNA}$ content was not significantly reduced relative to poly $(\mathrm{A})^{+}$RNA in liver, and alpha-tubulin mRNA content instead was increased in adrenal glands, showing that the decline in IGF-I mRNAs in these tissues was selective. In addition, spinal cord IGF-I mRNA content was significantly reduced per tissue, total RNA, and poly(A) ${ }^{+}$RNA after 1 and 2 weeks of diabetes. This was correlated with a concurrent and significant decrease in conduction velocity in both spinal cord and peripheral nerves in a separate study. The decline in liver and spinal cord IGF-I mRNA was not due to streptozotocin toxicity, because it was significantly opposed by insulin which was continuously infused beginning the day after diabetes induction. These results, when taken together with those of others, indicate that the reduction in IGF-I mRNA content may be widespread among diabetic tissues, and might contribute in part to certain syndromes of diabetes, such as neuropathy. [Diabetologia (1994) 37: 1073-1081]

Key words Insulin-like growth factor, somatomedin, diabetic neuropathy, conduction velocity.
Insulin-like growth factor I (IGF-I) is an anabolic growth mediator $[1,2]$ regulated by growth hormone $[3,4]$. Many tissues are known to produce IGF-I protein and mRNA [4-7], with liver being the predominant source of circulating IGF-I [8]. The growth rate is reduced in diabetes $[9,10]$ and IGF-I mRNA content is diminished in several diabetic tissues [11-13]. The extent of this biochemical pathology in diabetes deserves further study.

Received: 14 March 1994

and in revised form: 27 May 1994

Corresponding author: Dr. D. N. Ishii, Department of Physiology, Colorado State University, Fort Collins, CO 80523 USA

Abbreviations: IGF-I, Insulin-like growth factor I; SSC is $150 \mathrm{mmol} / 1 \mathrm{NaCl}$ and $15 \mathrm{mmol} / \mathrm{l}$ sodium citrate; STZ, streptozotocin; AUC, area under the curve.
Circulating IGF-I concentrations remain elevated long after the growth spurt [14], suggesting that, in addition to growth, IGF-I may serve to regulate other functions in mature vertebrates. Among such functions, emerging data suggest insulin and IGFs may play a prominant neurophysiological role, particularly in the development and maintenance of the neural circuitry [15]. This, in turn, has led to the hypothesis that a decline in IGF activity contributes to the pathogenesis of diabetic neuropathy [16]. This theory prompted Carsten et al. [17] to predict and find functional neuropathy in the spinal cord in an insulin ablation experiment. Fairly extensive observations now support the hypothesis that insulin and IGF-I may act together on neurons (see Discussion). It is possible, then, that the activity of IGF-I, as well as insulin, is important for support of neurons in diabetes.

The purpose of this study was to (a) add to the emerging evidence showing that disturbance in IGF- 
I mRNA content is widespread among diabetic tissues, and (b) test whether there is a decline in IGF-I mRNA content in diabetic liver and spinal cord sufficiently early to implicate a role for IGF-I in the development of complications in the nervous system.

\section{Materials and methods}

Materials. Oligo(dT) $)_{18}$ was obtained from Pharmacia (Piscataway, N.J., USA) and T4 polynucleotide kinase from Bethesda Research Laboratories (Gaithersburg, M.d., USA). Streptozotocin (STZ), porcine insulin, and glucose diagnostic kit 510 were purchased from Sigma Chemical Co. (St. Louis, Mo., USA). Mini-osmotic pump Model 2ML1 was from the ALZA Corp. (Palo Alto, Calif,, USA). Sprague-Dawley rats were obtained from Charles River Laboratories, Inc. (Wilmington, Mass., USA) or Harlan (Indianapolis, Ind., USA).

The human cDNA clone pKa1 contains the entire $\alpha$-tubulin coding region plus 67 and 173 base pairs of the $5^{\prime}$ and $3^{\prime}$ untranslated regions, respectively [18]. The clone pMH921 is a genomic 2.6 kilobase insert containing the complete coding region of the mouse histone 3.3 gene $[19,20]$. The IGF-I cDNA clone in pUC9 was a gift from Dr. A. Efstratiadis and contains the entire rat pre-pro-IGF-I coding sequence plus 340 nucleotides of $5^{\prime}$, and 69 nucleotides of $3^{\prime}$, non-coding sequence. This clone begins with nucleotide 1780 of exon 1 , contains no nucleotides from exon 4, and ends in nucleotide 718 of exon 5 of the sequence published by Shimatsu and Rotwein [21].

Experimental procedure. All studies involving rats were done in accordance with the principles of the NIH Guide for the Care and Use of Laboratory Animals. Rats were raised on $20 \mathrm{~g}$ per day standard rat chow until the study, and chow and water were provided ad libitum thereafter. Male rats (10 or 12-week-old) were randomly assorted into treatment groups, fasted overnight and anaesthesized with $80 \mathrm{mg} / \mathrm{kg}$ ketamine and $0.3 \mathrm{mg} / \mathrm{kg}$ acepromazine, i.p. Diabetes was induced in 12-week-old rats with i.v. $40-50 \mathrm{mg} / \mathrm{kg}$ STZ. STZ lots can have slightly different activity. Control rats were injected with an equivalent volume $(1 \mathrm{ml} / \mathrm{kg})$ of vehicle $(10 \mathrm{mmol} / \mathrm{l} \mathrm{so}-$ dium citrate, $0.9 \%$ sodium chloride, $\mathrm{pH} 4.5$ ). Plasma glucose concentrations were determined the following day using a glucose diagnostic kit. Only STZ-treated rats with greater than $22 \mathrm{mmol} / \mathrm{l}(400 \mathrm{mg} / \mathrm{dl})$ glucose in plasma were used in this study, except in the insulin infusion study for reasons discussed.

Miniosmotic pumps were implanted s.c. in the midback of some groups the day after STZ administration. The conditions were similar to those described to maintain normoglycaemia during constant insulin infusion [22]. The pumps were filled with either vehicle $(1.6 \%$ glycerin, $7 \mathrm{mg} / \mathrm{ml}$ glutamic acid, $0.2 \%$ phenol, $\mathrm{pH} 3.3$ ), or vehicle containing porcine insulin. The solutions were sterilized by passage through $0.2-\mu \mathrm{m}$ filters. Insulin concentrations were adjusted to deliver $58.5 \mathrm{nmol}$ ( 9.75 units) per $\mathrm{kg}$ body weight per day, and filled pumps were soaked in saline at $37^{\circ} \mathrm{C}$ for $2 \mathrm{~h}$ prior to implantation in order to decrease the time lag in release of solutions.

Preparation of RNA. Following killing with carbon dioxide, total RNA was immediately extracted from various tissues by the guanidinium thiocyanate procedure of Chomczynski and Sacchi [23]; $\mathrm{LiCl}$ was used to remove glycogen from liver samples [24]. RNA concentration and purity were estimated by A 260 and $280 \mathrm{~nm}$.
RNA electrophoresis and transfer to nitrocellulose. Equivalent amounts of RNA ( $40 \mu \mathrm{g}$ determined from absorbance measurements) were electrophoresed through $0.8 \%$ agarose gels containing formaldehyde, as described [25]. Ethidium bromide staining determined the position of $18 \mathrm{~S}$ and $28 \mathrm{~S}$ rRNAs and confirmed that equivalent amounts of undegraded RNA had been loaded. The RNA was transferred to nitrocellulose [26]. Alternatively, samples were heat-treated in formaldehyde, rapidly cooled on ice, and directly loaded ( $8 \mu \mathrm{g}$ in duplicate) onto high capacity BA85 nitrocellulose using a slot blot filtration device (Schleicher and Schuell, Keene, N.H., USA) similar to that described for dot blots [27]. RNA retention was linear up to at least $10 \mu \mathrm{g} / \mathrm{slot}$.

Hybridization to RNA. Nitrocellulose blots were hybridized to nick-translated [28] ${ }^{32} \mathrm{P}$-labelled DNA probes for $16-18 \mathrm{~h}$ at $42^{\circ} \mathrm{C}$. Single-stranded DNA probes were labelled to high specific activity using Taq primer extension [29] to study spinal cord RNA. Blots were washed for 45-60 min each with $2 \times$ wash buffer at $42^{\circ} \mathrm{C}, 2 \times$ wash buffer at $68^{\circ} \mathrm{C}$, twice with $1 \times$ wash buffer at $68^{\circ} \mathrm{C}$, and $0.5 \times$ wash buffer at $68^{\circ} \mathrm{C}$. Single-strength wash buffer (denoted as $1 \times$ ) contained $150 \mathrm{mmol} / \mathrm{l} \mathrm{NaCl}, 15 \mathrm{mmol} / \mathrm{l}$ sodium citrate, $10 \mathrm{mmol} / \mathrm{l}$ sodium phosphate, $0.03 \%$ pyrophosphate, and $0.05 \%$ sodium dodecylsulphate, $\mathrm{pH} 7.0$.

The procedure of Harley [30] was followed to end-label oligo(dT $)_{18}$. This reagent was used to measure poly $(A)^{+}$RNA. The slot blot filters were pre-soaked for $5 \mathrm{~min}$ in $5 \times \mathrm{SSC}$ $(1 \times \mathrm{SSC}$ is $150 \mathrm{mmol} / \mathrm{l} \mathrm{NaCl}, 15 \mathrm{mmol} / \mathrm{l}$ sodium citrate) and then hybridized for $1 \mathrm{~h}$ at $30^{\circ} \mathrm{C}$ with ${ }^{32} \mathrm{P}$-labelled oligo $(\mathrm{dT})_{18}$ $(1.02 \mathrm{nmol})$ in an $8.0 \mathrm{ml}$ solution containing $5 \times \mathrm{SSC}, 5 \times$ Denhardts, $10 \mathrm{mmol} / 1 \quad \mathrm{Na}_{2} \mathrm{HPO}_{4}, 1 \mathrm{mmol} / 1 \mathrm{Na}_{2} \mathrm{H}_{2} \mathrm{P}_{2} \mathrm{O}_{7}$, and $0.125 \%$ sodium dodecylsulphate. The filters were then washed three times for $5 \mathrm{~min}$ in $2 \times \mathrm{SSC}$ at $30^{\circ} \mathrm{C}$.

Boiling twice for $20 \mathrm{~min}$ in water was sufficient to remove all hybridized cDNA, as indicated by autoradiography, and some nitrocellulose blots were rehybridized to various cDNA or oligonucleotide probes.

Autoradiography and densitometry. Autoradiograms were prepared on X-ray film using Cronex Lightning Plus enhancing screens at $-70^{\circ} \mathrm{C}$, scanned on a GS 300 Scanning Densitometer connected to a computer, and data were analysed with the GS360 software package (Hoefer Scientific, San Francisco, Calif., USA). The best fit Gaussian curves were used to determine area under curves (AUC), which are reported in arbitrary units in the Figures and Tables. IGF-I mRNA per total RNA was calculated by dividing the IGF-I mRNA AUC values by total RNA loaded per sample, poly (A) ${ }^{+}$RNA per total RNA was calculated by dividing the oligo(dT) AUC values by total RNA loaded per sample, and IGF-I mRNA per poly $(\mathrm{A})^{+}$RNA was calculated by dividing the former by the latter. The linear range for measurements was determined by including a concentration series of RNA in blots, and by taking several autoradiographic exposures of different durations.

\section{Statistical analysis}

Statistical calculations were made with Student's $t$-test. Means and SEM are shown. 


\section{Results}

IGF-I mRNA content in liver. Rats (12 weeks old) were randomly assigned to two groups, one of which was treated with STZ to induce diabetes. After 8 days, RNA was isolated from the livers of both groups. Equivalent amounts of total RNA were analysed on blots to detect IGF-I mRNAs, poly $(\mathrm{A})^{+}$ RNA and histone 3.3 mRNA (Table 1). IGF-I mRNA content was significantly reduced in diabetic liver by about $93 \%$ whether measured relative to total RNA or poly $(\mathrm{A})^{+}$RNA. In contrast, histone 3.3 mRNA content was reduced to a lesser degree per total RNA, but this difference was not selective because it was not reduced per poly (A) ${ }^{+}$RNA. The relative mRNA pool size, estimated by the oligo(dT) hybridization, did not change appreciably. The results show that the sharp decline in IGF-I mRNA content in diabetic liver was not shared by the total mRNA pool.

Kinetics of IGF-I mRNA decline in liver. The rate of loss of IGF-I mRNA may provide clues as to the mechanism, as well as relationship to the decline in circulating IGF-I. The rate at which IGF-I mRNA was lost in RNA from diabetic liver is shown in Figure 1 . There was no detectible change in the IGF-I mRNA content on the first day following diabetes induction. Thereafter, there was a $55 \%$ decrease in IGF-I mRNA content between 1 and 2 days, no further change between 2 and 3 days, and a second decline of about $40 \%$ between 3 and 7 days. A spontaneous trend towards recovery between 1 and 10 weeks was seen, but only two animals were assayed at 10 weeks making it difficult to attribute significance to this observation.

Insulin infusion opposes the decline in liver IGF-I $m R N A$. The possibility that IGF-I mRNA levels might decline as a result of STZ toxicity to liver cells producing this transcript was investigated (Table 2). After STZ administration, rats had elevated plasma glucose concentrations at $20 \mathrm{~h}$ and were randomly assigned to two treatment groups.

Miniosmotic pumps were implanted subcutaneously $20 \mathrm{~h}$ post-treatment, and released either vehicle or insulin at a constant rate in a similar manner to that previously shown to maintain normoglycaemia [22]. RNA was extracted from livers of the two groups of diabetic rats 7 days after STZ administration. RNA was also isolated from a third group consisting of age-matched non-diabetic animals. The IGF-I mRNA levells were much lower in the diabetic rats treated with vehicle relative to untreated, nondiabetic rats. However, the IGF-I mRNA content remained significantly higher in the insulin-treated vs the vehicle-treated diabetic group, but did not quite return IGF-I mRNA content to normal despite attainment of nearly normal glucose concentrations.
Table 1. IGF-I mRNA and histone $3.3 \mathrm{mRNA}$ content, relative to total RNA and poly $(\mathrm{A})^{+}$RNA, in diabetic rat liver

\begin{tabular}{lll}
\hline Assay & $\begin{array}{l}\text { Non-diabetic } \\
(\%)^{\mathrm{a}}\end{array}$ & $\begin{array}{l}\text { Diabetic } \\
(\%)\end{array}$ \\
\hline $\begin{array}{l}\text { IGF-I mRNA } \\
\text { per total RNA }\end{array}$ & $100 \pm 11$ & $7.1 \pm 2.1^{\mathrm{b}}$ \\
per poly(A) ${ }^{+}$RNA & $100 \pm 15$ & $7.3 \pm 2.1^{\mathrm{b}}$ \\
$\begin{array}{l}\text { Histone 3.3 mRNA } \\
\text { per total RNA }\end{array}$ & $100 \pm 7$ & $67 \pm 15^{\mathrm{c}}$ \\
per poly(A) ${ }^{+}$RNA & $100 \pm 16$ & $77 \pm 15$ \\
\hline
\end{tabular}

Rats (12-weeks-old) were injected either with STZ to induce diabetes or an equal volume of vehicle. Eight days later, total RNA was isolated from livers, and analysed $(8 \mu \mathrm{g})$ on a slot blot. The filter was hybridized in succession to ${ }^{32} \mathrm{P}$-labelled clone pMH921 and oligo(dT) in order to detect histone 3.3 mRNA and poly(A) ${ }^{+}$RNA, respectively. Autoradiograms of both this slot blot, and a Northern blot detecting IGF-I mRNA, were scanned on a densitometer, and a computerized program was used to measure the relative area under each curve (AUC).

${ }^{a}$ The relative $A U C$ values are means $\pm \operatorname{SEM}(n=$ samples from five rats run in duplicate), and are percentages relative to non-diabetic values.

${ }^{\mathrm{b}} p<0.005$ between samples from diabetic and non-diabetic rats.

${ }^{c} p<0.05$ between samples from diabetic and non-diabetic rats

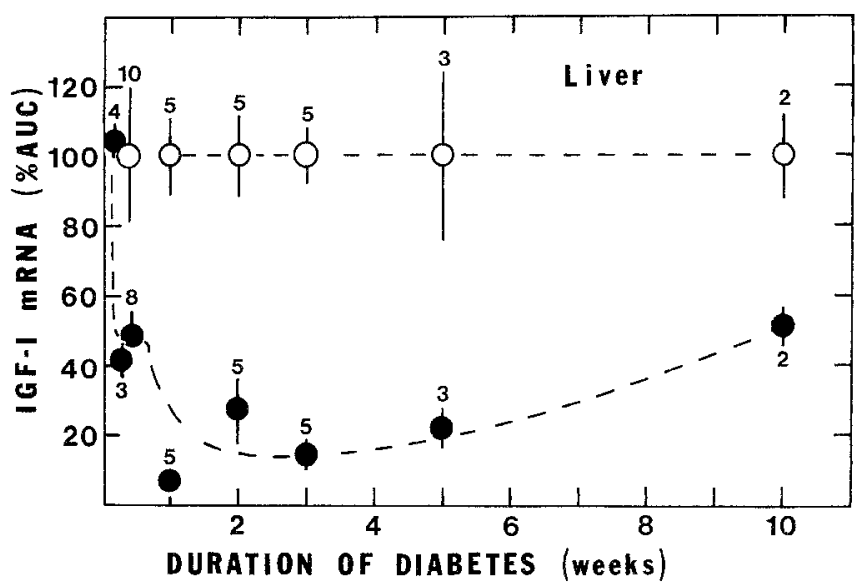

Fig. 1. Effect of diabetes duration on the kinetics of decline of IGF-I mRNA content in liver. Rats (12 weeks old) were randomly assigned into two treatment groups. Groups were injected with either vehicle alone (non-diabetic), or STZ to induce diabetes. At various times thereafter, as indicated, groups of animals were assayed. RNA was isolated from liver and equivalent amounts ( $8 \mu \mathrm{g}$ per slot) analysed for IGF-I mRNA content. The values are means \pm SEM (number of animals in group shown next to symbol) of AUC shown as percentages relative to age-matched non-diabetic rats. Where $n=2$ at 10 weeks, the values instead are ranges. $(O)$, diabetic; $(O)$, non-diabetic

These results unequivocally showed that the decline in IGF-I mRNA levels was not the result of STZ toxicity to liver cells producing this transcript. Insulin was capable of inhibiting the decline in IGF-I mRNA content, even though its infusion was not started until 1 day after the STZ treatment. 
Table 2. Effect of insulin infusion on serum glucose and liver IGF-I mRNA levels in rats treated with STZ

\begin{tabular}{lllll}
\hline Treatment & $\mathrm{N}$ & \multicolumn{2}{l}{ Glucose $(\mathrm{mmol} / \mathrm{l})$} & \\
\cline { 2 - 3 } & & $20 \mathrm{~h}$ & 1 week & IGF-I mRNA (AUC) \\
\hline Non-diabetic & 4 & $\mathrm{ND}$ & $5.6 \pm 0.4$ & $100 \pm 6$ \\
Diabetic + vehicle & 5 & $16.3 \pm 2.1$ & $31.3 \pm 3.5$ & $32 \pm 3$ \\
Diabetic + insulin & 5 & $17.2 \pm 1.2$ & $6.9 \pm 1.3^{\mathrm{b}}$ & $56 \pm 9^{\mathrm{c}}$ \\
\hline
\end{tabular}

Rats (12 weeks old) were administered STZ and plasma glucose levels were determined after $20 \mathrm{~h}$. The rats were randomly assigned to two groups, both of which were implanted s.c. with miniosmotic pumps. The pumps delivered either 58.5 nmol insulin $\cdot \mathrm{kg}$ body weight ${ }^{-1} \cdot$ day $^{-1}$ or vehicle only. One week after the diabetes induction, plasma glucose levels were determined, and RNA was purified from liver and analysed for relative IGF-I mRNA content on a Northern blot. A third group of untreated non-diabetic animals were also included.

Prior to removing liver, blood samples were taken. The mean plasma glucose concentration in insulintreated diabetic rats was significantly reduced relative to the mean in vehicle-treated diabetic rats, and was slightly but not significantly elevated relative to the mean in normal animals. This slight elevation could be traced to two diabetic rats that had relatively high plasma glucose concentrations (9.9 and $10.0 \mathrm{mmol} / \mathrm{l})$, and very low IGF-I mRNA levels, despite insulin-treatment. Whether this was due to poor pump performance resulting from occlusion or due to other causes is not known.

IGF-I mRNA content in adrenal glands. To study whether IGF-I mRNA content is reduced in other diabetic tissues, the adrenal glands were examined (Fig. 2). Animals were 10 or 12 weeks old at the onset of the study, and were assayed after 5 or 10 weeks' diabetes duration. The adrenal IGF-I mRNAs were more abundant and about the same in size as the various transcripts observed in neonatal brain and muscle, but the content was profoundly reduced in all diabetic adrenal glands (Fig. $2 \mathrm{a}$ ). This autoradiogram was scanned on a densitometer, and there was a significant difference $(p<0.005)$ between non-diabetic and diabetic samples: $769 \pm 196$ $(n=4)$, non-diabetic; $99 \pm 19(n=6)$, diabetic. There was an $87 \%$ decline in the amount of IGF-I mRNA relative to total RNA in adrenal glands, which was comparable to the $93 \%$ decline observed earlier in liver. When data from only the 5 -week diabetic rats were considered, the IGF-I mRNA content was also significantly reduced $(p<0.005)$. The blot was boiled and rehybridized to ${ }^{32} \mathrm{P}$-labelled cDNA clone $\mathrm{pK} \alpha 1$ (Fig. 2b). $\alpha$-Tubulin mRNA was increased, rather than decreased, relative to total RNA: $664 \pm 55$ $(n=4)$, non-diabetic; $948 \pm 30 \quad(n=6)$ diabetic $(p<0.005)$.

The same adrenal RNA samples ( $8 \mu \mathrm{g} /$ lane) were analysed further on slot blots by hybridization successively to ${ }^{32} \mathrm{P}$-labelled IGF-I cDNA and oligo(dT) as
The rats were not fasted prior to glucose assay because of the possibility of hypoglycaemia in the group receiving continuous insulin infusion.

${ }^{a}$ The AUC of densitometric scans is shown. The values are means $\pm S E M$, shown as percentages relative to non-diabetic values. $n=$ number of animals. ND, not determined.

${ }^{\mathrm{b}} p<0.0005$ between the two diabetic groups.

${ }^{c} p<0.025$ between the two diabetic groups

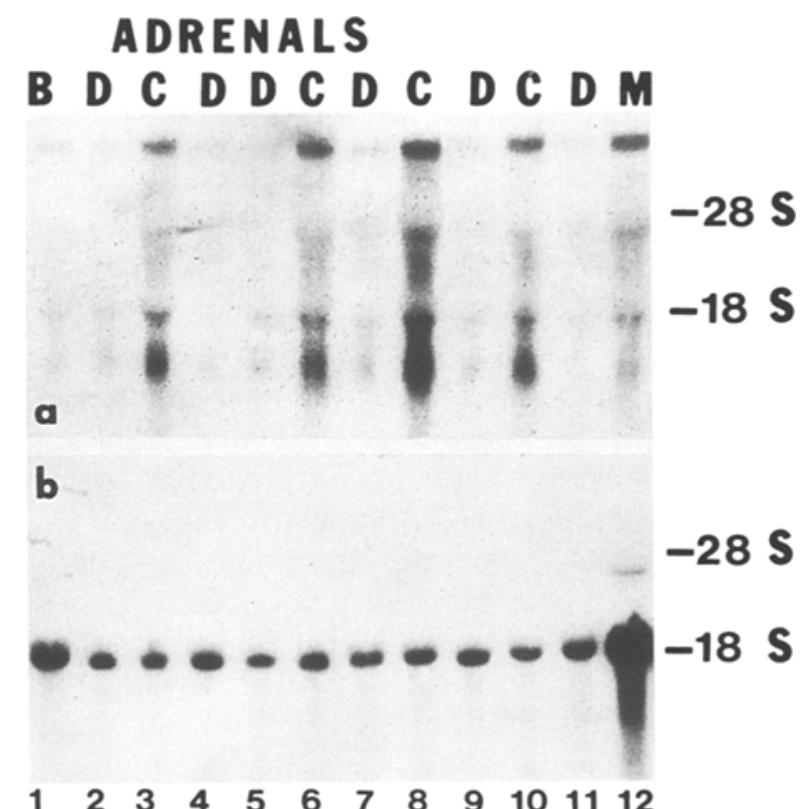

Fig. 2. Effect of diabetes on abundance of IGF-I and tubulin mRNAs in adrenal glands. Rats (10 and 12 weeks old) were randomly assorted into two groups, one of which was treated with STZ to induce diabetes. After 5 (lanes 2-9) or 10 (lanes 10 and 11) weeks of diabetes, RNA was isolated from adrenal glands. Equivalent amounts of RNA $(40 \mu \mathrm{g})$ from each sample were electrophoresed in $0.8 \%$ agarose gels containing formaldehyde. Ethidium bromide staining confirmed that equal amounts of undegraded RNA were present in each lane, and revealed the presence of 18 and $28 \mathrm{~S}$ rRNA bands. Following transfer to nitrocellulose, the samples were hybridized to a nick-translated cDNA containing the coding sequence of rat IGF-I. A print of the autoradiogram is shown (a). The mean AUC values were decreased in diabetic animals $(p<0.005)$. The blot was stripped and rehybridized to nicktranslated cDNA clone pKa1 to detect $\alpha$-tubulin mRNAs (b). Tubulin mRNA levels (mean AUC values) were elevated in diabetic animals $(p<0.005)$. C, non-diabetic control; $\mathrm{D}$, diabetic; B, 2-day-old rat brain; M, 4-day-old skeletal muscle 
Table 3. IGF-I mRNA content relative to total RNA and poly $(A)^{+}$RNA in diabetic rat adrenal glands

\begin{tabular}{lllll}
\hline Treatment & $n$ & $\begin{array}{l}\text { IGF-I mRNA } \\
\text { per total RNA }\end{array}$ & $\begin{array}{l}\text { Poly(A) }{ }^{+} \text {RNA } \\
\text { per total RNA }\end{array}$ & $\begin{array}{l}\text { IGF-I mRNA } \\
\text { per poly(A) })^{+} \text {RNA }\end{array}$ \\
\hline $\begin{array}{l}\text { Non-diabetic } \\
\text { Diabetic }\end{array}$ & 4 & $100 \pm 16$ & $100 \pm 10$ & $100 \pm 7$ \\
& 6 & $12 \pm 3^{\mathrm{a}}$ & $101 \pm 6$ & $13 \pm 3^{\mathrm{a}}$ \\
\hline
\end{tabular}

Samples of RNA ( $8 \mu \mathrm{g} / \mathrm{lane})$ from the experiment shown in Figure 2 were analysed further on a slot blot. The blot was hybridized first to detect IGF-I mRNA, boiled, and rehybridized to detect poly $(\mathrm{A})^{+}$RNA using ${ }^{32}$ P-labelled oligo(dT). The relative AUC values in arbitrary units are means \pm SEM ( $n=$ number of animals), shown as percentages relative to non-diabetic values.

${ }^{\text {a }} \mathrm{P}<0.0005$ between non-diabetic and diabetic groups

Table 4. Total RNA and IGF-I mRNA content in diabetic rat spinal cord

\begin{tabular}{|c|c|c|c|c|c|}
\hline \multirow[t]{2}{*}{ Treatment } & \multirow[t]{2}{*}{$n$} & \multirow{2}{*}{$\begin{array}{l}\text { RNA } \\
\text { per cord }\end{array}$} & \multicolumn{3}{|c|}{ IGF-I mRNA } \\
\hline & & & per cord & per RNA & per poly $(\mathrm{A})^{+}$RNA \\
\hline Non-diabetic & 8 & $187 \pm 13$ & $100 \pm 18$ & $100 \pm 15$ & $100 \pm 9$ \\
\hline 8 days & 4 & $204 \pm 9$ & $46 \pm 9^{a}$ & $51 \pm 8^{a}$ & $91 \pm 6$ \\
\hline 14 days & 4 & $206 \pm 7$ & $39 \pm 5^{b}$ & $44 \pm 5^{b}$ & $57 \pm 7^{c}$ \\
\hline
\end{tabular}

Rats (12 weeks old) were randomly assigned into two groups, and injected either with vehicle or STZ. RNA was isolated from whole spinal cords of non-diabetic animals, and rats diabetic for 8 and 14 days. The total RNA per cord was determined ( $\mu \mathrm{g})$. Equivalent amounts of total RNA ( $8 \mu \mathrm{g} / \mathrm{lane})$ were loaded on slot blots and hybridized to detect IGF-I
mRNA and poly(A) ${ }^{+}$RNA. Relative AUC values are shown as means \pm SEM ( $n=$ number of animals $)$ in percentages relative to non-diabetic values. Diabetic and non-diabetic groups were compared.

${ }^{\mathrm{a}} \mathrm{P}<0.05 ;{ }^{\mathrm{b}} \mathrm{P}<0.025 ;{ }^{\mathrm{c}} \mathrm{P}<0.01$ shown in Table 3 . The IGF-I mRNA content was significantly decreased relative to both total RNA and poly(A) ${ }^{+}$RNA in adrenal glands from diabetic rats. However, no statistical difference was found in oligo(dT) hybridization between RNA from non-diabetic and diabetic rats, showing that the poly $(\mathrm{A})^{+}$ RNA pool size was unchanged relative to total RNA. The data for adrenal glands, as for liver, show that IGF-I mRNA transcripts are selectively reduced in diabetes.

IGF-I $m R N A$ content in spinal cord. The IGF-I gene is expressed in rodent CNS $[4,6]$. The profile of spinal cord IGF-I mRNAs on Northern blots was similar to that of brain. IGF-I mRNA content was reduced in diabetic cord (Fig. 3).

The content of total RNA, poly (A) ${ }^{+}$RNA, and IGF-I mRNA was measured in spinal cords from rats which were 12 weeks old at the onset, had been treated with $40 \mathrm{mg} / \mathrm{kg} \mathrm{STZ}$, and had been diabetic for 8 and 14 days (Table 4). The IGF-I mRNA content was profoundly (50-60\%) and significantly decreased per spinal cord and per total RNA in rats that had been diabetic for 8 and 14 days, and significantly decreased per poly (A) ${ }^{+}$RNA at 14 days. The total RNA content per spinal cord was not significantly different between non-diabetic and diabetic rats.

Using a slightly higher STZ concentration (47 mg/ $\mathrm{kg}$ ), IGF-I mRNA content per poly(A) ${ }^{+}$RNA was found to be significantly reduced $(p<0.005)$ in diabetic rats (vehicle) as early as 1 week after induction

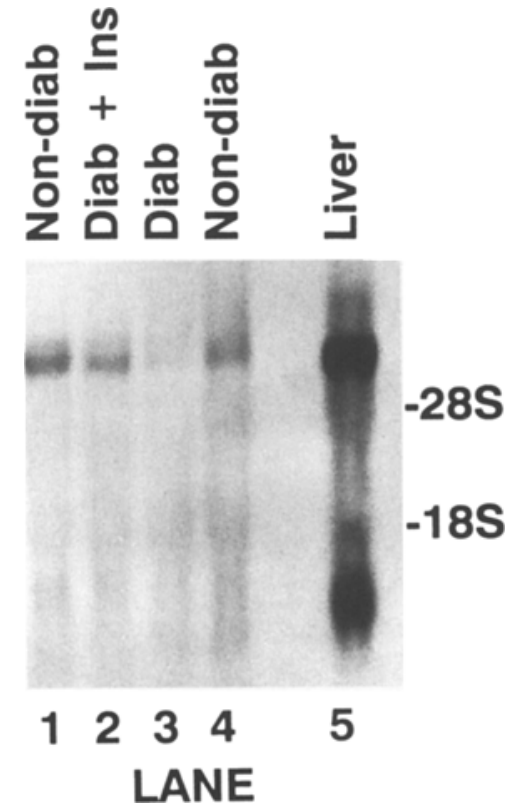

Fig. 3. Effect of diabetes on IGF-I mRNAs in spinal cord. Rats (12 weeks old) were randomly assigned into groups. Some were non-diabetic untreated controls, and others were made diabetic with $47 \mathrm{mg} / \mathrm{kg}$ STZ. Diabetic rats were confirmed to be diabetic by glucose assay at $20 \mathrm{~h}$, and implanted with miniosmotic pumps that released vehicle or insulin $(58.5 \mathrm{nmol} \cdot \mathrm{kg}$ body weight $^{-1} \cdot$ day $^{-1}$ ). One week later, RNA was isolated from spinal cords and equivalent amounts ( $40 \mu \mathrm{g} /$ lane) analysed on Northern blots to detect IGF-I mRNAs. Adult liver RNA $(10 \mu \mathrm{g} / \mathrm{lane})$ is shown for comparison. Ethidium bromide staining confirmed that equivalent amounts of RNA had been transferred to blots, and revealed the position of $18 \mathrm{~S}$ and $28 \mathrm{~S}$ rRNA bands. Lanes 1 and 4, non-diabetic; lane 2, insulin-treated diabetic; lane 3, vehicle-treated diabetic; and lane 5, liver 
Table 5. Effect of insulin infusion on spinal cord IGF-I mRNA content in rats treated with STZ

\begin{tabular}{lccl}
\hline Treatment & $n$ & $\begin{array}{c}\text { IGF-I mRNA per } \\
\text { poly(A) }\end{array}$ & $\begin{array}{l}\text { poly(A) }{ }^{+} \text {RNA } \\
\text { per total RNA }\end{array}$ \\
\hline Non-diabetic & 3 & $100 \pm 6$ & $100 \pm 8$ \\
Diabetic (vehicle) & 4 & $60 \pm 6^{\mathrm{a}}$ & $110 \pm 13$ \\
Diabetic (insulin) & 4 & $81 \pm 6^{\mathrm{b}}$ & $106 \pm 10$
\end{tabular}

Rats (12 weeks old) were treated with STZ and implanted with pumps that released either insulin or vehicle, in the same experiment described in Figure 3. One week after the induction of diabetes, RNA was isolated. Slot blots with equivalent amounts of spinal cord RNA $(8 \mu \mathrm{g} / \mathrm{slot})$ were hybridized to detect IGF-I mRNA. Blots were stripped and rehybridized to detect poly(A) ${ }^{+}$RNA. Non-diabetic rats were also studied. The relative AUC values in arbitrary units are means \pm SEM ( $n=$ number of rats) shown as percentages relative to non-diabetic values.

${ }^{a} P<0.005$, diabetic (vehicle) vs non-diabetic group.

${ }^{\mathrm{b}} P<0.05$, diabetic (insulin) vs diabetic (vehicle) group

of diabetes at 12 weeks of age (Table 5). STZ toxicity to spinal cord cells was probably not the cause of this reduction, because the loss of IGF-I mRNAs could be prevented by infusion of insulin from a miniosmotic pump after STZ treatment. IGF-I mRNA content per $\operatorname{poly}(\mathrm{A})^{+}$RNA was significantly increased $(p<0.05)$ in insulin-treated vs vehicle-treated diabetic spinal cords. On the other hand, the poly $(\mathrm{A})^{+}$ RNA content per RNA in spinal cord was unchanged whether rats were diabetic or treated with insulin. The glucose content was significantly reduced in the insulin-treated $(8.9 \pm 2.2 \mathrm{mmol} / 1, n=4)$ vs vehicletreated $(44.9 \pm 2.9 \mathrm{mmol} / \mathrm{l}, n=4)$ diabetic rats.

Animal weights and glucose concentrations. IGF-I mRNA content is known to decline in starved animals $[11,12]$. Because diabetic animals can weigh less, the effect of diabetes on animals weights and glucose concentrations, under the conditions of this study, was measured. Non-diabetic animals showed $4 \%$ weight gain, but diabetic animals lost about $15 \%$ of their initial weight in 2 weeks. There was a significant $(p<0.05) 20 \%$ decrease in weights of diabetic ( $349 \pm 8 \mathrm{~g}, n=6$ rats) relative to non-diabetic rats $(438 \pm 12 \mathrm{~g}, n=6)$. Glucose concentrations were significantly $(p<0.05)$ elevated in diabetic $(32.9 \pm 2.1$ $\mathrm{mmol} / \mathrm{l}, n=6)$ relative to non-diabetic $(6.2 \pm 0.3$ $\mathrm{mmol} / \mathrm{l}, n=6$ ) rats at 2 weeks post-treatment. In another study diabetic rats lost about $6 \%$ (not significant) of their initial weight, and were $17 \%$ lighter $(p<0.05, n=5)$ than non-diabetic rats, after 8 days.

\section{Discussion}

IGF-I mRNA content was substantially and selectively diminished in liver, adrenals, and spinal cord of diabetic rats. Others have previously shown de- creases in diabetic liver, kidney, heart, and lung [12, 13]. Taken together, these results support the suggestion that a reduction in IGF-I mRNA content is widespread among diabetic tissues. Certain syndromes of diabetes might be explained by this reduction.

IGF-I mRNA content in diabetic liver was selectively reduced. The reduction in circulating IGF-I concentration in diabetic rats [31-33] is likely to be closely tied to the profound fall in liver IGF-I mRNA. It is estimated that the $31 \mu \mathrm{g} /$ day produced in liver could account for almost all of the circulating concentration of about $800 \mathrm{ng} / \mathrm{ml}[8,34]$. In the two 10 -week diabetic rats, there appeared to be partial recovery of liver IGF-I mRNA content. This might have resulted from the slow regeneration of pancreatic islet cells, which is well known, but this possibility was not investigated.

IGF-I mRNA content was reduced in adrenal glands of only some rats at 1 and 2 weeks diabetes duration (not shown). However, at 5-10 weeks diabetes, IGF-I mRNA content was consistently and significantly reduced relative to total RNA, poly $(\mathrm{A})^{+}$ RNA, and $\alpha$-tubulin mRNAs in diabetic adrenal glands. The relative content of poly $(\mathrm{A})^{+} \mathrm{RNA}^{+}$in total RNA from this tissue was unchanged.

The presence of IGF-I transcripts in human [35] and rat adrenal glands is consistent with the report that adrenal cells can secrete IGF-I [36]. Insulin and IGF receptors are present on chromaffin cells [36], suggesting that IGF-I may play an autocrine or paracrine role. The low IGF-I mRNA content in diabetic adrenal glands makes it difficult to avoid the implication of a potential relationship to the reduced epinephrine response to hypoglycaemia in diabetes [ 37 , 38]. Involvement of chromaffin cells might be considered in the context of autonomic neuropathy. It is difficult to cleanly dissect medulla from cortex in the rat, and rat cDNA probes might be inappropriate to hybridize to adrenal RNA from other species because of the possibility of cross-hybridization at lower stringency to other members of the insulin/IGF gene family. Alternatively, in situ hybridization might be attempted. Further study is needed to establish whether the IGF-I mRNA is from cortex, medulla, or both tissues.

Autopsy reveals degeneration of the spinal cord in diabetic patients [39-41]. Unlike peripheral neuropathy, myelopathy is not presently considered a significant complication in diabetes. However, the case for involvement of the central nervous system is growing. For example, visual and auditory evoked potentials are abnormal early after onset of clinical diabetes [42]. Spinal cord degeneration [43], including reduction in perikaryal volume of ventral horn neurons [44], is also found in diabetic rats. Thus, rats may provide a useful experimental model in which to study myelopathy. The present observation of an early biochemical disturbance in IGF-I mRNA con- 
tent in rat spinal cord adds to this growing list showing that the central nervous system is not spared in diabetes.

IGF-I mRNA content is significantly reduced per tissue, per total RNA, and per poly $(\mathrm{A})^{+}$RNA in spinal cord from diabetic rats. In a separate experiment (not shown), $\alpha$-tubulin mRNA content was unchanged, providing further evidence for the selectivity of the decline in IGF-I mRNAs. These effects are observed after only 1 and 2 weeks of diabetes and rank among the earliest detectable biochemical changes observed in neural tissues.

It is striking that, under the same experimental conditions, conduction velocity is predicted and found to be reduced (at 1 and 2 weeks) in spinal cord of rats rendered diabetic with STZ [17]. A similar rate of decline in conduction velocity is observed in peripheral nerves. Loss of IGF-I mRNA in liver, as well as in spinal cord, may contribute to neuropathy. Infused IGFs can enhance nerve regeneration $[45,46]$, indicating that circulating IGF-I may support the nervous system. From this viewpoint, it may be pertinent that the kinetics of loss of IGF-I mRNA in liver is similar to the rate of decline of conduction velocity in spinal cord and peripheral nerves in a separate study with different animals [17]. Yang et al. [11] found somewhat slower kinetics in younger rats treated with higher STZ doses.

The prediction of Carsten et al. [17] was based on emerging evidence that insulin and IGFs may act together on neurons to support the neural circuitry (for greater detail see [15]). IGF-I mRNAs are present in brain $[6,7,21]$ and spinal cord. Moreover, insulin $[48,49]$, IGF-I [50], and their receptors [51-53], are found in the CNS. These factors can support neurite outgrowth in cultured sensory, sympathetic [54], and motor neurons [55]. Survival of peripheral and central neurons is also supported [54, 56]. IGF-I increases sensory nerve regeneration distances [57] and motor axon sprouting [55] in vivo. Recently, a close correlation has been found between the development and regeneration of neuromuscular synapses and the expression of IGF-I [58] and IGF-II [59] genes.

Insulin and IGFs support neurite outgrowth in part by increasing expression of genes encoding structural proteins of axons and dendrites, such as tubulins [60] and neurofilaments [61]. Microtubules, comprised of tubulin subunits, are long, tubular elements of axons and dendrites contributing both to the cytoskeleton and to rapid anterograde and retrograde transport. The 68 and $170 \mathrm{kDa}$ neurofilament proteins assemble into neurofilaments which form part of the axonal cytoskeleton, and are suggested to regulate the diameter of axons [62].

These observations may be significant in understanding the pathogenesis of this enigmatic disorder $[63,64]$. There can be loss of ganglion cells, de- creased numbers and diameters of axons, diminished transport [65], and reduced conduction velocity in diabetic neuropathy. These pathological changes might be considered in light of the decline in serum IGF-I, evident when the data are corrected for age in diabetic patients [66]. Rhesus monkeys provide an interesting model of non-insulin-dependent diabetes [67]. Young, lean monkeys begin with normal glucose and insulin levels. As animals age, weight is gained, insulin levels become elevated, and impaired glucose tolerance begins to emerge, which progresses to overt hyperglycaemia. It is striking that serum IGF-I levels are progressively reduced in parallel with these age-dependent changes, but are not correlated with either glycaemic state or insulinaemia. Neuropathy is seen in diabetic rhesus monkeys [68]. A more detailed account of the theory linking IGF activity to the pathogenesis of experimental and clinical diabetic neuropathy will appear elsewhere [16]. Acute episodes in insulin-dependent diabetes are associated both with reduced IGF-I activity and transient neuropathy $[69,70]$. At the same time, although these may be contributory factors, it is prudent to consider that diabetes is a complex disorder, and neuropathy is believed by many to arise as a direct or indirect result of hyperglycaemia. Further study of this provocative correlation between IGF activity and neuropathy is needed.

IGF-I protein and mRNA contents in liver probably do not decline as a result of STZ toxicity. For example, the administration of insulin following STZ induction of diabetes can antagonize the decline in both IGF-I mRNA and circulating somatomedin [31, 71]. Moreover, insulin can restore serum IGF-I levels towards normal in pancreatectomized dogs [72], showing that this capacity of insulin to correct IGF-I concentrations is present in diabetic tissues never exposed to STZ.

Moreover, the IGF-I mRNA content in spinal cord probably did not decline as a result of STZ toxicity. However, one may not entirely exclude the possibility that insulin can increase IGF-I mRNA content in diabetic spinal cord directly, rather than by preventing STZ toxicity. Insulin ameliorated the loss of IGF-I mRNAs that occurred in STZ-treated diabetic rats. Insulin also prevents impairment of conduction velocity in STZ-treated diabetic rats [17].

The reduced IGF-I mRNA content in liver is due in part to a decline in growth hormone secretion in rats [73]. There is tissue resistance to growth hormone as well, because treatment of diabetic rats with growth hormone does not induce IGF-I [32]. Tissue resistance is not due to a reduction in growth hormone receptor mRNA in liver [12], and growth hormone binding remains normal in rats diabetic for 1 week, although IGF-I levels are reduced [31]. Much less is known about the basis for the decline in IGF-I mRNA content in diabetic tissues other than liver. 
Acknowledgements. We thank Argiris Efstratiadis and John Welsh of Columbia University, N. Y. for generously providing their rat IGF-I cDNA clone. We also thank Gerry Huitt for providing fine technical assistance. This work was supported by grant RO1 NS24327 from the National Institute of Neurological Disorders and Stroke.

\section{References}

1. Phillips LS, Vassilopoulou-Sellin R (1980) Somatomedins. N Engl J Med 302: 371-380; 438-446

2. Schoenle E, Zapf J, Humbel RE, Froesch ER (1982) Insulin-like growth factor I stimulates growth in hypophysectomized rats. Nature (Lond) 296: 252-253

3. Schalch DS, Heinrich OE, Draznin B, Johnson CJ, Miller LL (1979) Role of the liver in regulating somatomedin activity: hormonal effects on the synthesis and release of insulin-like growth factor and its carrier protein by the isolated perfused liver. Endocrinology 104: 1143-1151

4. Mathews LS, Norstedt G, Palmiter RD (1986) Regulation of insulin-like growth factor I gene expression by growth hormone. Proc Natl Acad Sci. USA 83: 9343-9347

5. D'Ercole AJ, Stiles AD, Underwood LE (1984) Tissue concentrations of somatomedin $\mathrm{C}$ : further evidence for multiple sites of synthesis and paracrine or autocrine mechanisms of action. Proc Natl Acad Sci USA 81: 935-939

6. Lund PK, Moates-Staats BM, Hynes MA, Simmons JG, Jansen M, D'Ecole AJ, Van Wyk JJ (1986) SomatomedinC/insulin-like growth factor-I and insulin-like growth factor-II mRNAs in rat fetal and adult tissues. $\mathbf{J}$ Biol Chem 261: 14539-544

7. Murphy LJ, Bell GI, Friesen HG (1987) Tissue distribution of insulin-like growth factor I and II messenger ribonucleic acid in the adult rat. Endocrinology 120: 1279-1282

8. Schwander JC, Hauri C, Zapf J, Froesch ER (1983) Synthesis and secretion of insulin-like growth factor and its binding protein by the perfused rat liver: dependence on growth hormone status. Endocrinology 113: 297-305

9. Pond H (1970) Some aspects of growth in diabetic children. Postgrad Med J [Suppl 46]: 616-623

10. Birbeck JA (1972) Growth in juvenile diabetes mellitus. Diabetologia 8: 221-224

11. Yang H, Scheff AJ, Schalch DS (1990) Effects of streptozotocin-induced diabetes mellitus on growth and hepatic insulin-like growth factor I gene expression in the rat. Metabolism 39: 295-301

12. Bornfeldt KE, Arnqvist HJ, Enberg B, Mathews LS, Norstedt G (1989) Regulation of insulin-like growth factor-I and growth hormone receptor gene expression by diabetes and nutritional state in rat tissues. J Endocrinol 122:651-656

13. Fagin JA, Roberts CT Jr, LeRoith D, Brown AT (1989) Coordinate decrease of tissue insulin-like growth factor I posttranscriptional alternative mRNA transcripts in diabetes mellitus. Diabetes 38: 428 -434

14. Hall K, Sara VR (1984) Somatomedin levels in childhood, adolescence and adult life. Clin Endocrinol Metab 13: 91 112

15. Ishii DN (1993) Neurobiology of insulin and insulin-like growth factors. In: Loughlin SE, Fallon JH (eds) Neurotrophic factors. Academic Press, New York, pp 415-442

16. Ishii DN (1994) Implication of insulin-like growth factors in the pathogenesis of diabetic neuropathy. Brain Res Rev in press

17. Carsten RE, Whalen LR, Ishii DN (1989) Impairment of spinal cord conduction velocity in diabetic rats. Diabetes 38: $730-736$
18. Cowan NJ, Dobner PR, Fuschs EV, Cleveland DW (1983) Expression of human alpha-tubulin genes: interspecies conservation of 3' nontranslated regions. Mol Cell Biol 3: 1738-1745

19. Wellman SE, Casano PJ, Pilch DR, Marzluff WF, Sittman DB (1987) Characterization of mouse H3.3-like histone genes. Gene 59: 29-39

20. Brown DT, Wellman SE, Sittman DB (1985) Changes in the levels of three different classes of histone mRNA during murine erythroleukemia cell differentiation. Mol Cell Biol 5: 2879-2886

21. Shimatsu A, Rotwein P (1987) Mosaic evolution of the in sulin-like growth factors: organization, sequence, and expression of the rat insulin-like growth factor I gene. J Biol Chem 262: 7894-7900

22. Patel DG (1983) Rate of insulin infusion with a minipump required to maintain a normoglycemia in diabetic rats (41529). Proc Soc Exp Biol Med 172: 74-78

23. Chomczynski P, Sacchi N (1987) Single-step method of RNA isolation by acid guanidinium thiocyanate-phenolchloroform extraction. Anal Biochem 162: 156-159

24. Puissant C, Houdebine L-M (1990) An improvement of the single-step method of RNA isolation by acid guanidinium thiocyanate-phenol-chloroform extraction. Bio Techn 8: 148-149

25. Lehrach H, Diamond D, Wozney JM, Boedtker H (1977) Ribonucleic acid molecular weight determination by gel electrophoresis under denaturing conditions, a critical reexamination. Biochemistry 16: 4743-4751

26. Thomas PS (1980) Hybridization of denatured RNA and small DNA fragments transferred to nitrocellulose. Proc Natl Acad Sci USA 77: 5201-5205

27. Kafatos F, Jones CW, Efstratiadis A (1979) Determination of nucleic acid sequence homologies and relative concentrations by a dot hybridization procedure. Nucleic Acids Res 7: 1541-1553

28. Rigby PW, Dieckmann M, Rhodes C, Berg P (1977) Labelling deoxyribonucleic acid to high specific activity in vitro by nick translation with DNA polymerase I. J Mol Biol 113: $237-251$

29. Mizobuchi M, Frohman LA (1992) A rapid and simple method for labeling short DNA fragments using Taq polymerase. BioTechn 12: 350-354

30. Harley CB (1987) Hybridization of oligo(dT) to RNA on nitrocellulose. Gene Anal Tech 4: 17-22

31. Maes M, Ketelslegers J-M, Underwood LE (1983) Low plasma somatomedin-C in streptozotocin-induced diabetes mellitus. Correlation with changes in somatogenic and lactogenic liver binding sites. Diabetes 32: 1060-1069

32. Phillips LS, Young HS (1976) Nutrition and somatomedin. II. Serum somatomedin activity and cartilage growth activity in streptozotocin-diabetic rats. Diabetes 25: 516-527

33. Baxter RC, Brown AS, Turtle JR (1979) Decrease in serum receptor-reactive somatomedin in diabetes. Horm Metab Res 11: 216-220

34. Scott CD, Martin JL, Baxter RC (1985) Production of insulin-like growth factor I and its binding protein by adult rat hepatocytes in primary culture. Endocrinology 116: 1094-1101

35. Han VKM, D'Ercole AJ, Lund PK (1987) Cellular localization of somatomedin (insulin-like growth factor) messenger RNA in the human fetus. Science 236: 193-198

36. Penhoat A, Naville D, Jaillard C, Chatelain PG, Saez JM (1989) Hormonal regulation of insulin-like growth factor I secretion by bovine adrenal cells. J Biol Chem 264: 68586862

37. Bolli G, De Feo P, Compagnucci P, Cartechini MG, Angeletti G, Santeusanio F, Brunetti P (1982) Important role of 
adrenergic mechanisms in acute glucose counterregulation following insulin-induced hypoglycemia in type I diabetes: evidence for an effect mediated by beta-adrenoceptors. Diabetes 31: 641-647

38. Polonsky K, Bergenstal R, Pons G, Schneider M, Jaspan J, Rubenstein A (1982) Relation of counterregulatory responses to hypoglycemia in type I diabetics. N Engl J Med 307: 1106-1112

39. Woltman HW, Wilder RM (1929) Diabetes mellitus: pathologic changes in spinal cord and peripheral nerves. Arch Intern Med 44: 576-603

40. Olsson Y, Save-Soderbergh J, Sourander P, Angervall LA (1968) Patho-anatomical study of the central and peripheral nervous system in diabetes of early onset and long duration. Pathol Eur 3: 62-79

41. Slager UT, Webb AT (1973) Pathologic findings in the spinal cord. Arch Pathol 96: 388-394

42. Pozzessere G, Rizzo PA, Valle E et al. (1988) Early detection of neurological involvement in IDDM and NIDDM: multimodal evoked potentials versus metabolic control. Diabetes Care 11: 473-480

43. Felten DL (1979) Spinal cord alterations in streptozotocininduced diabetes. Anat Rec 193: 741-742

44. Sidenius P, Jakobsen J (1980) Reduced perikaryal volume of lower motor and primary sensory neurons in early experimental diabetes. Diabetes 29: 182-187

45. Near SL, Whalen LR, Miller JA, Ishii DN (1992) Insulinlike growth factor-II stimulates motor nerve regeneration. Proc Natl Acad Sci USA 89: 11716-11720

46. Glazner GW, Lupien S, Miller JA, Ishii DN (1993) Insulinlike growth factor-II increases the rate of sciatic nerve regeneration in rats. Neuroscience 54: 791-797

47. Recio-Pinto E, Ishii DN (1984) Effects of insulin, insulinlike growth factor-II and nerve growth factor on neurite outgrowth in cultured human neuroblastoma cells. Brain Res 302: 323-334

48. Havrankova J, Roth J, Brownstein M (1978) Insulin receptors are widely distributed in the central nervous system of the rat. Nature (Lond) 272: 827-829

49. Hill JM, Lesniak MA, Pert CB, Roth J (1986) Autoradiographic localization of insulin receptors in rat brain: prominence in olfactory and limbic areas. Neuroscience 17:11271138

50. Noguchi T, Kurata LM, Sugisaki T (1987) Presence of a somatomedin C-immunoreactive substance in the central nervous system: immunohistochemical mapping studies. Neuroendocrinology 46: 277-282

51. Yip CC, Moule ML, Yeung CWT (1980) Characterization of insulin receptor subunits in brain and other tissues by photoaffinity labeling. Biochem Biophys Res Commun 96: 1671-1678

52. Sara VR, Hall K, von Holtz H, Humbel R, Sjögren B, Wetterberg L (1982) Evidence for the presence of specific receptors for insulin-like growth factors 1 (IGF-I) and 2 (IGF-II) and insulin throughout the adult human brain. Neurosci Lett 34: 39-44

53. Burgess SK, Jacobs S, Cuatrecasas P, Sahyoun N (1987) Characterization of a neuronal subtype of insulin-like growth factor I receptor. J Biol Chem 262: 1618-1622

54. Recio-Pinto E, Rechler MM, Ishii DN (1986) Effects of insulin, insulin-like growth factor-II, and nerve growth factor on neurite formation and survival in cultured sympathetic and sensory neurons. J Neurosci 6: 1211-1219

55. Caroni P, Grandes P (1990) Nerve sprouting in innervated adult skeletal muscle induced by exposure to elevated levels of insulin-like growth factors. J Cell Biol 110: 13071317
56. Aizenman Y, de Vellis J (1987) Brain neurons develop in a serum and glial free environment: effects of transferrin, insulin, insulin-like growth factor-I and thyroid hormone on neuronal survival, growth and differentiation. Brain Res 406: 32-42

57. Kanje M, Skottner A, Sjöberg J, Lundborg G (1989) Insulin-like growth factor I (IGF-I) stimulates regeneration of the rat sciatic nerve. Brain Res 486: 396-398

58. Glazner GW, Ishii DN (1989) Relationship of insulin-like growth factor I mRNA content to synaptogenesis in rat muscle. Soc Neurosci Abstr 15: 1353 (Abstract)

59. Ishii DN (1989) Relationship of insulin-like growth factor II gene expression in muscle to synaptogenesis. Proc Natl Acad Sci USA 86: 2898-2902

60. Mill JF, Chao MV, Ishii DN (1985) Insulin, insulin-like growth factor II, and nerve growth factor effects on tubulin mRNA levels and neurite formation. Proc Natl Acad Sci USA 82: $7126-7130$

61. Wang C, Li Y, Wible B, Angelides KJ, Ishii DN (1992) Effects of insulin and insulin-like growth factors on neurofilament mRNA and tubulin mRNA content in human neuroblastoma SH-Y5Y cells. Mol Brain Res 13: 289-300

62. Hoffman PN, Cleveland DW, Griffin JW, Landes PW, Cowan NJ, Price DL (1987) Neurofilament gene expression: a major determinant of axonal caliber. Proc Natl Acad Sci USA 84: $3472-3476$

63. Thomas PK, Eliasson SG (1984) Diabetic neuropathy. In: Dyck PJ, Thomas PK, Lambert EH, Bunge R (eds) Peripheral neuropathy. Volume 2, W.B. Saunders Company, Philadelphia, pp 1773-1810

64. Dyck PJ, Thomas PK, Asbury AK, Winegrad AI, Porte D Jr (1987) Diabetic neuropathy, W.B. Saunders Company, Philadelphia

65. Jakobsen J, Sidenius P (1980) Decreased axonal transport of structural proteins in streptozotocin diabetic rats. J Clin Invest 66: 292-297

66. Tan K, Baxter RC (1986) Serum insulin-like growth factor I levels in adult diabetic patients: the effect of age. J Clin Endocrinol Metab 63: 651-655

67. Bodkin NL, Sportsman R, DiMarchi RD, Hansen BC (1991) Insulin-like growth factor-I in non-insulin-dependent diabetic monkeys: basal plasma concentrations and metabolic effects of exogenously administered biosynthetic hormone. Metabolism 40: 1131-1137

68. Cornblath DR, Dellon AL, MacKinnon SE (1989) Spontancous diabetes mellitus in a rhesus monkey: neurophysiological studies. Muscle Nerve 12: 233-235

69. Winter RJ, Phillips LS, Green OC, Traisman HS (1980) Somatomedin activity in the Mauriac syndrome. J Pediatr 97 : $598-600$

70. Blethen SL, Sargeant DT, Whitlow MG, Santiago JV (1981) Effect of pubertal stage and recent blood glucose control of plasma somatomedin-C in children with insulindependent diabetes mellitus. Diabetes 30: 868-872

71. Phillips LS, Orawski AT (1977) Nutrition and somatomedin. III. Diabetic control, somatomedin, and growth in rats. Diabetes 26: 864-869

72. Froesch ER, Schlumpf U, Heimann R, Eigenmann E, Zapf J (1975) NSILA-S, physiologic and pharmacologic significance as an insulin-like hormone and as a growth-promoting hormone. Adv Metab Disord 8: 237-245

73. Harrison HE, Robinson TE (1980) Impaired growth hormone secretion in streptozotocin diabetic rats. Horm $\mathrm{Me}$ tab Res 12: 556-557 